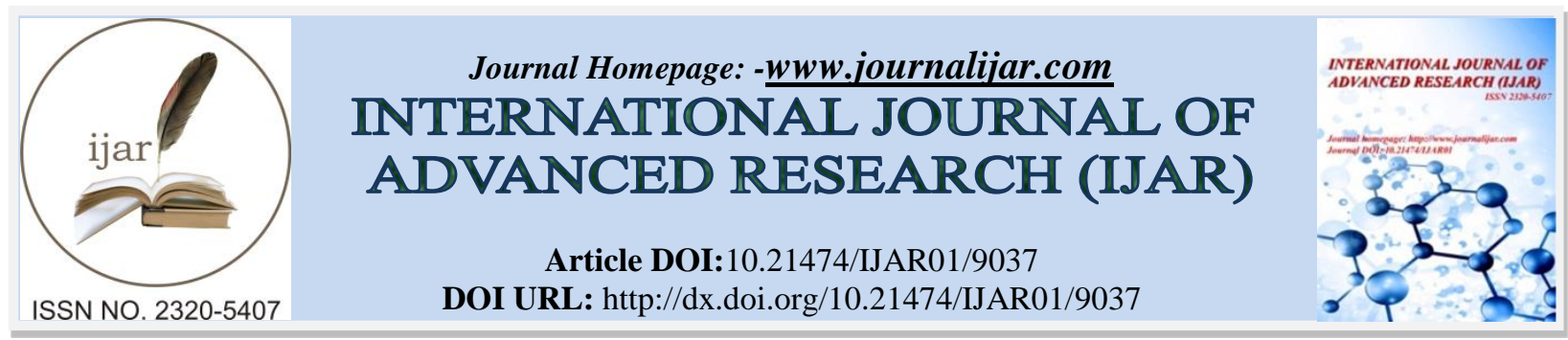

RESEARCH ARTICLE

\title{
ESTIMATION OF SOIL EROSION HAZARD IN SOME WADIS OF THE NORTH WESTERN COAST- EGYPT USING RUSLE MODEL AND GIS.
}

Mohamed. M. Shoman.

RS \& GIS Unit, Soils, Water and Environment Research Institute, Agricultural Research Center, GIZA, Egypt.

\section{Manuscript Info}

\section{Manuscript History}

Received: 10 March 2019

Final Accepted: 12 April 2019

Published: May 2019

\section{Key words:-}

NWC: RS and GIS; Soil Loss; Soil erosion; RUSLE; Land Use Land Cover map.

\section{Abstract}

Assessment of soil erosion loss is useful in the development of plans and protection for watershed and basins, causing this phenomenon of land degradation and loss of nutrients and decrease of water available to plants. RUSLE model integrated with GIS has been used to estimate soil loss in Wadi Umm Ashtan and Wadi Umm El-Rakham basins located in the North West Coast (NWC) of Egypt. Annual rainfall data, digital elevation model (DEM), land-use classification map and soil map were used to generate the RUSLE parameters such as rainfall erosivity factor (R), Length slope factor (LS), soil erodability factor $(\mathrm{K})$, vegetation cover factor $(\mathrm{C})$ and erosion control factor $(\mathrm{P})$. Depending on the results obtained, it was found that the highest value of predicted soil erosion of wadi Umm Ashtan is 562.8 tone/ha/year. As for wadi Umm El-Rakham, the highest value of predicted soil erosion is 211.6 tone/ha/year. According to erosion hazard classification suggested by Singh et al. (1992), Soil erosion of Wadi Umm Ashtan and Wadi Umm El-Rakham basins are classified into 6 classes: Slight ( $99.4 \%$ and $99.3 \%$ of total area respectively), moderate $(0.4 \%$ and $0.6 \%$ of total area respectively), high $(0.1 \%$ and $0.1 \%$ of total area respectively), with very small areas of very high, severe and very severe classes.

The results can certainly aid in implementation of soil management and conservation practices to reduce the soil erosion in Wadi Umm Ashtan and Wadi Umm El-Rakham basins.

Copy Right, IJAR, 2019,. All rights reserved.

\section{Introduction:-}

Soil degradation due to soil erosion is a global phenomenon leading to the loss of surface soils potential due to the loss of nutrients and increase of the runoff and decrease of water availability of plants. Soil erosion risk varies from case to case depending on the configuration of the watershed (topography, shape), the soil characteristics, the local climatic conditions and the land use and management practices implemented. For these reasons, determining soil loss and the detecting of exposed areas and capability to erosion are essential factors to develop management plans and practices for successful soil conservation.

However, the difficulty of estimating soil erosion comes from the complex interplay of many factors, such as climate, topography, soil, land cover, and human activities. Soil erosion models can provide a better understanding

Corresponding Author:-Mohamed. M. Shoman.

Address:-RS \& GIS Unit, Soils, Water and Environment Research Institute, Agricultural Research Center, GIZA, Egypt. 
of natural phenomena. Several different models have been proposed to predict and describe soil erosion degrees by surface runoff of water. They vary widely in their objectives, standards and spatial measures. Since traditional methods have proven to be very expensive and time-consuming methods of extracting input data, these are major problem in the application of corrosion models, namely the lack of input data availability. But with the advent of remote sensing techniques, acquiring spatial information about input data has become easier and cost-effective. Multi-temporal satellite data provide valuable information on seasonal land use, corrosive features such as canyons, rainfall interstitial conflict, and vegetation factor.

A number of methods have been developed to assess the potential for soil erosion. Currently there are two ways to estimate the potential of corrosion. The first is an experimental method based mainly on experience. The second is the revised formula for global soil loss (RUSLE), an update of the global soil loss equation (USLE). Based on information on soil and climate data.

The global revised formula for soil loss (RUSLE) is the dominant model applied worldwide for predicting soil loss because of its applicability to and compatibility with GIS (Millward and Mersey, 1999; Lu et al., 2004; Dabral et al., 2008; Pandey et al., 2009). Although it is a pilot model, it predicts not only the rates of erosion of untapped watersheds based on watershed characteristics and local climatic conditions, but also the spatial heterogeneity of soil erosion, which is highly feasible at reasonable costs and better accuracy in larger areas (Angima et al. , 2003).

The main objective of the study is producing soil loss map identifying the areas in Wadi Umm Ashtan and Wadi Umm El-Rakham basins exposed to soil erosion by surface runoff and also to estimate the amount of loss of the soil using RULSE equation integrated with GIS for put necessary plans, measures and policies to protect the soil of erosion hazard.

\section{Material and methods:}

\subsection{Study Area:}

The study was conducted at the North West Coast (NWC) of the western desert of Egypt in Matrouh Governorate (about18 km west of Mersa Matruh city) as shown in Figure 1.

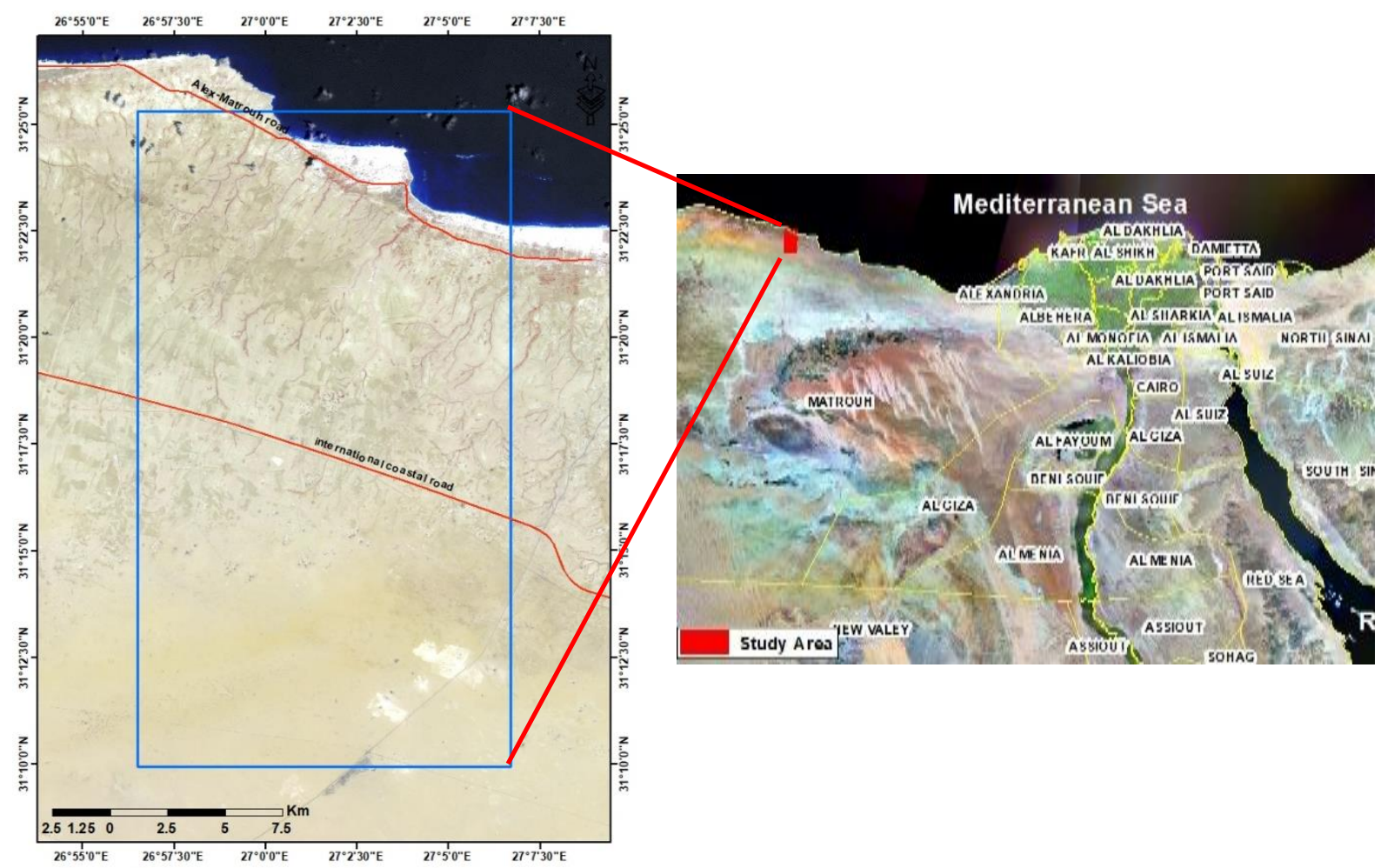

Figure 1:-Location and Satellite data of the study area 
The study area is located between latitudes $31^{\circ} 09^{\prime} 57.6^{\prime \prime}$ to $31^{\circ} 25^{\prime} 18.5^{\prime \prime} \mathrm{N}$, longitudes $26^{\circ} 56^{\prime} 30.3^{\prime \prime}$ to $27^{\circ} 06^{\prime}$ 41.0" E. over an area of 45837 ha (about $458.4 \mathrm{~km}^{2}$ ). Two main roads pass through the study area, Alex-Matrouh road that passes in the northern part of the study area and international coastal road, which passes in the middle part of the study area (Figure 2).

\subsection{Fieldwork and laboratory analyses}

Fifty-soil profiles were selected according to the geomorphic units and the homogeny level of the studied area. Soil profiles were morphologically described according to a manual of the soil survey staff (2012) and soil samples were collected according to the differences between the layers. Particle size distribution, organic matter content and bulk density were determined according to USDA (2004).

About 50 observation points were collected by Global Positioning System (GPS) devices from the study area used as training samples for classification to define a different land cover class and some observation points were used in the accuracy assessment process.

\subsection{Satellite data:}

Planet high-resolution visible and an infrared sensor (3 m spatial resolution) acquired in September 2018 used for Supervised Maximum Likelihood classification for land cover class. The satellite image was Georeferenced to the Universal Transverse Mercator (UTM) projection.

\subsection{Metrological data:}

According to Metrological data of Mersa Matrouh station from 2001 to 2015 obtained from Central Laboratory for Agriculture Climate (CLAC) and showed in Table (1) This area is classified as arid with mild winter and warm summer (UNESCO, 1977).

\subsection{Remote sensing \& GIS software:}

ERDAS IMAGINE 2014 as remote sensing processing software was used for Supervised Maximum Likelihood classification for land cover class, ArcGIS V. 10.4.1 software (ESRI, 2016) as GIS software which include raster calculator tool allows to create and execute a map Algebra expression for many of thematic maps that will output a final raster and calculate the areas of output classes.

Table 1:-Meteorological data of Mersa Matrouh area (2001- 2015)

\begin{tabular}{|c|c|c|c|c|c|}
\hline Year & $\begin{array}{c}\text { Mean } \\
\text { Temperature }\left({ }^{\circ} \mathbf{C}\right)\end{array}$ & $\begin{array}{c}\text { Max. } \\
\text { Temperature }\left({ }^{\circ} \mathbf{C}\right)\end{array}$ & $\begin{array}{c}\text { Min. } \\
\text { Temperature }\left({ }^{\circ} \mathbf{C}\right)\end{array}$ & $\begin{array}{c}\text { Relative } \\
\text { Humidity }(\boldsymbol{\%})\end{array}$ & $\begin{array}{c}\text { Rainfall } \\
(\mathbf{m m})\end{array}$ \\
\hline $\mathbf{2 0 0 1}$ & 20.34 & 24.98 & 15.55 & 66.25 & 98.30 \\
\hline $\mathbf{2 0 0 2}$ & 20.36 & 24.81 & 15.70 & 67.03 & 183.10 \\
\hline $\mathbf{2 0 0 3}$ & 20.14 & 24.72 & 15.57 & 66.40 & 160.53 \\
\hline $\mathbf{2 0 0 4}$ & 20.07 & 24.54 & 15.55 & 62.63 & 93.98 \\
\hline $\mathbf{2 0 0 5}$ & 20.03 & 24.13 & 15.94 & 62.34 & 103.37 \\
\hline $\mathbf{2 0 0 6}$ & 20.00 & 24.40 & 15.67 & 65.55 & 114.55 \\
\hline $\mathbf{2 0 0 7}$ & 20.17 & 24.48 & 15.75 & 67.52 & 263.13 \\
\hline $\mathbf{2 0 0 8}$ & 20.68 & 25.21 & 16.05 & 65.74 & 137.16 \\
\hline $\mathbf{2 0 0 9}$ & 20.38 & 24.76 & 15.80 & 63.28 & 109.50 \\
\hline $\mathbf{2 0 1 0}$ & 21.13 & 25.90 & 16.48 & 62.98 & 87.12 \\
\hline $\mathbf{2 0 1 1}$ & 20.03 & 24.42 & 15.59 & 66.06 & 185.72 \\
\hline $\mathbf{2 0 1 2}$ & 20.71 & 25.07 & 16.34 & 67.11 & 103.62 \\
\hline $\mathbf{2 0 1 3}$ & 20.52 & 25.01 & 16.08 & 67.48 & 120.39 \\
\hline $\mathbf{2 0 1 4}$ & 20.71 & 25.43 & 16.06 & 68.20 & 60.96 \\
\hline $\mathbf{2 0 1 5}$ & 20.38 & 25.15 & 15.75 & 68.47 & 86.37 \\
\hline Average and & $\mathbf{2 0 . 3 8}$ & $\mathbf{2 4 . 8 7}$ & $\mathbf{1 5 . 8 6}$ & $\mathbf{6 5 . 8 0}$ & $\mathbf{1 9 0 7 . 8 0}$ \\
\hline Sum & & & & \\
\hline
\end{tabular}

*source: Central Laboratory for Agricultural Climate (CLAC, 2015).

Data showed that means of annual rainfall ranged from $263.13 \mathrm{~mm}$ during 2007 to $60.96 \mathrm{~mm} \mathrm{during} 2014$ (increasing from West to East and from South to North). Mean of annual temperature was $20.38^{\circ} \mathrm{C}$, and the maximum annual temperature ranged from $25.9^{\circ} \mathrm{C}$ in 2010 to $24.13{ }^{\circ} \mathrm{C}$ in 2005 , while the minimum annual 
temperature ranged from $15.55^{\circ} \mathrm{C}$ in 2007 to $16.48^{\circ} \mathrm{C}$ in 2010 . The average of annual humidity ranged from $68.47 \%$ in 2015 to $62.34 \%$ in 2005 .

\subsection{Digital Elevation Model (DEM):}

Digital elevation model (DEM) that has been derived from sentinel-2A sensor of $12.5 \mathrm{~m}$ resolution is used in the present study area (Figure 2).

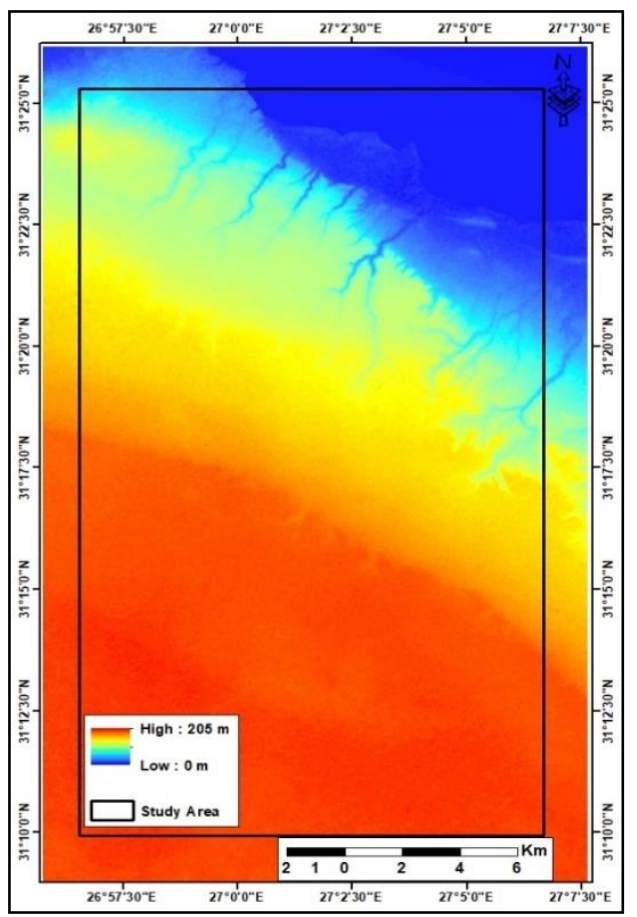

Figure 2:-Digital elevation model (DEM) of the study area

\subsection{DEM Hydro-processing:}

DEM Hydro processing of the starting of flow direction and flow accumulation and ending with basins and catchments extraction (Figure 3).

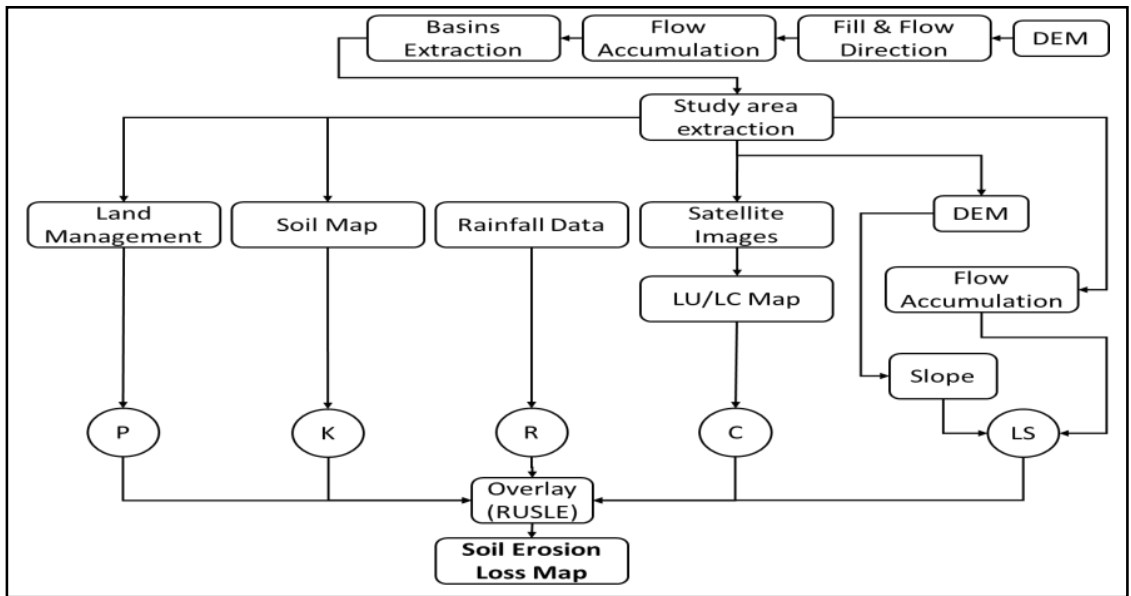

Figure 3:-Flow chart for modelling of soil erosion loss

\subsection{Revised Universal Soil Loss Equation (RUSLE)}

This model illustrates the effect of climate, soil, topography, and land use on soil erosion in sloping terrain caused by raindrop and surface runoff impact. It has been used widely to estimate soil erosion loss, to evaluate soil erosion 
risk, to guide development plans and to control erosion under different land cover conditions, such as croplands, rangelands, and disturbed forestlands. The RUSLE is showed as:

Where:

$$
\mathrm{A}=\mathrm{R} \times \mathrm{K} \times \mathrm{LS} \times \mathrm{C} \times \mathrm{P}
$$

$\mathrm{A}=$ Average annual soil loss in in tone/ha/year

$\mathrm{R}=$ Rainfall/runoff erosivity $\left(\mathrm{MJ} \cdot \mathrm{mm} \cdot \mathrm{ha}^{-1} \cdot \mathrm{h}^{-1} \cdot \mathrm{year}^{-1}\right)$

$\mathrm{K}=$ Soil erodibility (tone $\mathrm{h} / \mathrm{MJ} / \mathrm{mm}$ )

LS = Slope Length and Steepness Factor

$\mathrm{C}=$ Cover-management

$\mathrm{P}=$ Support practice factor

\subsubsection{Rainfall/runoff erosivity (R-factor)}

$\mathrm{R}$ factor is a measure of erosivity of rainfall which is the outcome of storm kinetic energy. When other factors are constant, storm losses from rainfall are directly symmetrical to the outcome of the total kinetic energy of the storm times its maximum 30-minute intensity. (Arnoldus, 1978). Most of the national meteorological stations do not have rainfall intensity and storm kinetic energy data. For that, annual and monthly rainfall data have been used to estimate the R factor. (Arnoldus, 1978)

\subsubsection{Soil Erodibility Index (K factor)}

Soil erodibility factor illustrates both sensitivity of soil to erosion and runoff. The factor values are affected by texture, organic matter content, permeability and structural stability of the soil. (Renard et al., 1991).

\subsubsection{Slope and Slope Length (LS) Factors}

Factors L and S represents land topography and the effects of slope length and slope angle on soil erosion. (Edwards, 1987)

\subsubsection{Cover management factor $(\mathrm{C})$}

This factor estimates the amount of soil surface protection from erosion by vegetation and other land changes. C factor values changes with the density of land cover where values decrease with good soil protection and decrease with tilled, bare and ridged soils. (Van der Knijff et al., 2000).

\subsubsection{The Support Practice (P Factor)}

This factor applied to disordered lands and illustrates how management practices are used to reduce soil erosion by many processes such as terracing, contouring and strip cropping. This value is close to 1.0 with areas that do not have support practice (Simms A.D 2003).

\subsection{Soil erosion loss map production.}

For identifying and map production of the areas vulnerable to soil erosion, thematic maps for RUSLE factors were integrated by raster algebra module in ArcGIS software. Output thematic map represents the areas which are most vulnerable and least exposed to erosion risk due to surface runoff.

\section{Results And Discussion:-}

\subsection{Study area extraction:}

As previously mentioned, according to DEM Hydro processing of the starting of flow direction, flow accumulation and ending with identify basin and catchment areas, fifteen main basins were located in the area (Figure 4-a). 


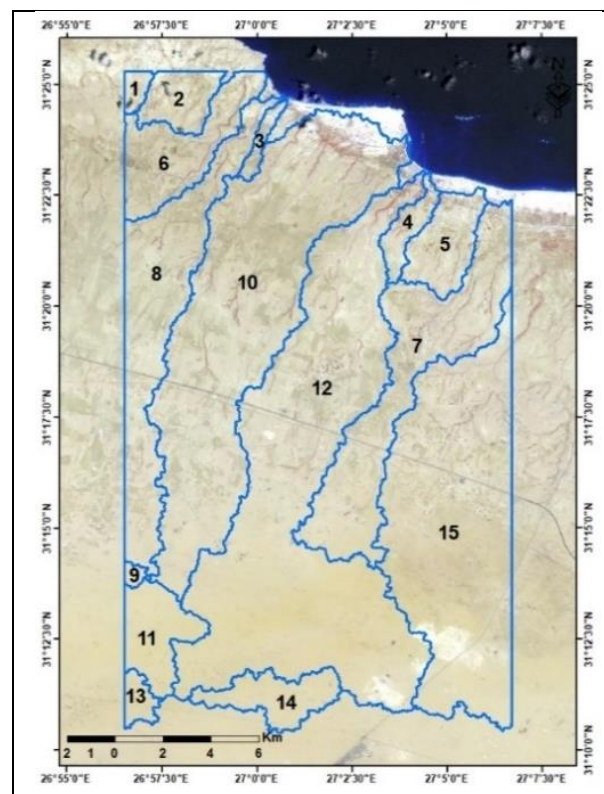

(a) Basins extraction

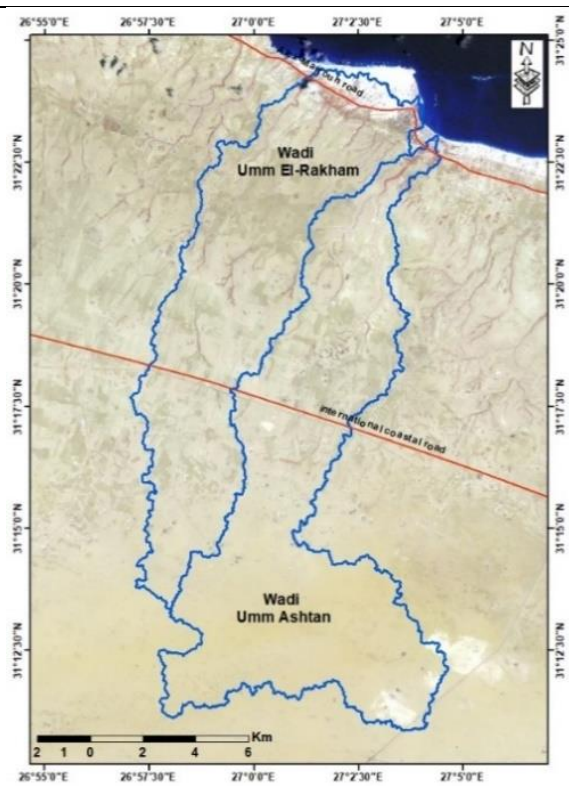

(b) Wadi Umm Ashtan \& Wadi Umm El-Rakham basins

Figure 4:-(a) Basins extraction and (b) Wadi Umm Ashtan and Wadi Umm El-Rakham basins

Wadi Umm Ashtan and Wadi Umm El-Rakham basins with minimum stream length of 10000 meter of the studied area were selected according to diversity in altitudinal zones and slopes classes (Figure 4-b). Wadi Umm Ashtan is located between latitudes $31^{\circ} 10^{\prime} 49.975^{\prime \prime}$ to $31^{\circ} 23^{\prime} 4.188^{\prime \prime} \mathrm{N}$, longitudes $26^{\circ} 57^{\prime} 41.292^{\prime \prime}$ to $27^{\circ} 04^{\prime} 39.346^{\prime \prime} \mathrm{E}$. over an area of 10584 ha (about $105.8 \mathrm{~km}^{2}$ ). While Wadi Umm El-Rakham is located between latitudes $31^{\circ} 13^{\prime} 20.436^{\prime \prime}$ to $31^{\circ} 24^{\prime} 28.942^{\prime \prime} \mathrm{N}$, longitudes $26^{\circ} 57^{\prime} 2.249^{\prime \prime}$ to $27^{\circ} 04^{\prime} .112^{\prime \prime} \mathrm{E}$. over an area of 8369 ha (about $83.7 \mathrm{~km}^{2}$ ). DEM of wadi Umm Ashtan and wadi Umm El-Rakham were extracted to represent the study area. Flow accumulation and slope degree for both wadies (Figures 5-6) were generated using spatial analyst module in ArcGIS software.

DEM values of wadi Umm Ashtan ranged from 0 to 203 and Slope values ranged from 0 to 29 degree. While DEM values of wadi Umm El-Rakham ranged from 0 to 203 and Slope values ranged from 0 to 30.6 degree.

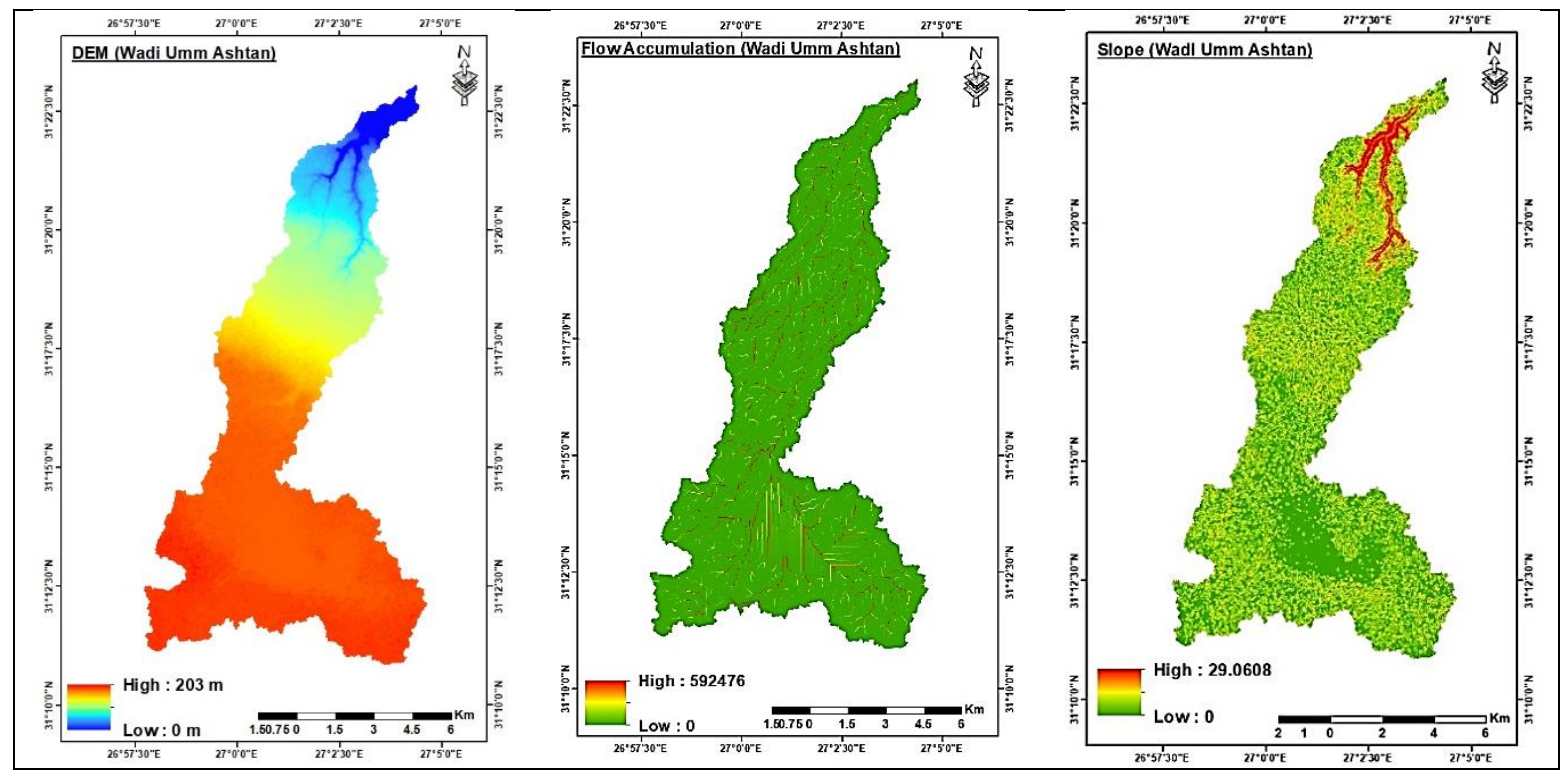

Figure 5:-DEM, Flow Accumulation, Slope degree of Wadi Umm Ashtan 


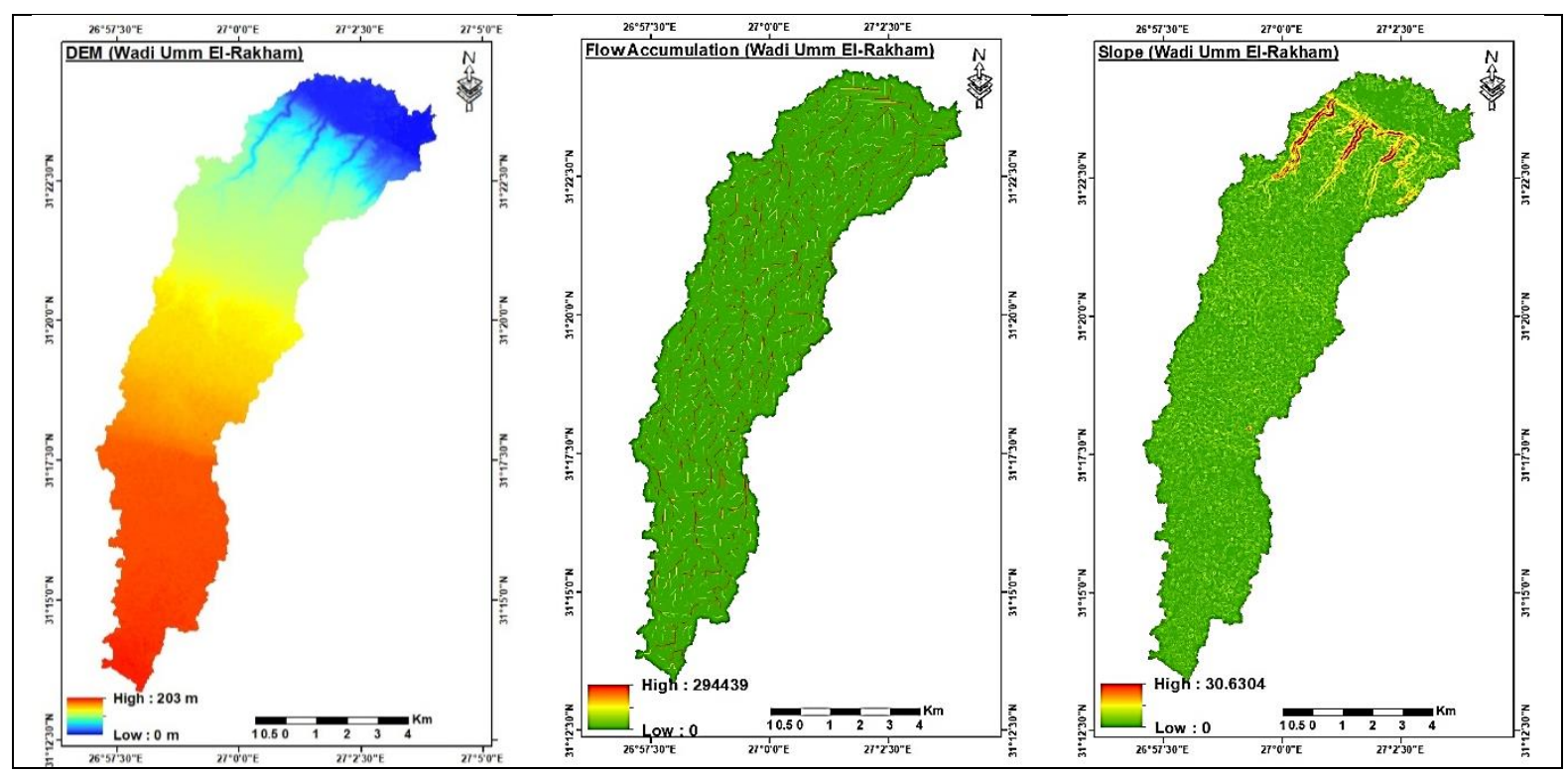

Figure 6:-DEM, Flow Accumulation, Slope degree of Wadi Umm El-Rakham

RUSLE parameter estimation:

Rainfall erosivity factor $(\mathbf{R})$ :

In the present study, yearly rainfall data of 15 years (2000 to 2015) were used to calculate the $\mathrm{R}$ factor from the following equation developed by Kassam et al.,1992:

$$
\mathrm{R}=117.6 \times 1.00105^{\mathrm{p}}
$$

Where: $\mathrm{R}=$ rainfall erosivity factor $\left(\mathrm{MJ} \cdot \mathrm{mm} \cdot \mathrm{ha}^{-1} \cdot \mathrm{h}^{-1} \cdot \mathrm{year}^{-1}\right)$.

$\mathrm{P}=$ mean annual rainfall $(\mathrm{mm})$

Moreover, where the study area has one meteorological Stations (marsa Matrouh meteorological Station), the calculated value of $\mathrm{R}$ factor for the study area is $137.4 \mathrm{MJ} \cdot \mathrm{mm} \cdot \mathrm{ha}^{-1} \cdot \mathrm{h}^{-1}$.year ${ }^{-1}$.

Soil Erodibility Index (K factor)

According to laboratory analysis of particular size distribution, structure, permeability, and organic matter content, $\mathrm{K}$ factor was calculated for the study area using equation given by (Wischmeier and Smith 1978) as shown below:

Where:

$$
100 \mathrm{~K}=2.1 \times 10^{-4} \times \mathrm{M}^{1.14} \times(12-\mathrm{a})+3.25(\mathrm{~b}-2)+2.5(\mathrm{c}-3)
$$

$\mathrm{K}=$ Soil erodibility (tone $\mathrm{h} / \mathrm{MJ} / \mathrm{mm}$ )

$\mathrm{M}=($ very fine sand $\%+$ Silt $\%) \times(100-$ Clay $\%)$.

$\mathrm{a}=$ Organic Matter Content $\%$.

$\mathrm{b}=$ Soil structure Code (values ranging from 1 to 4 ).

$\mathrm{c}=$ Permeability/drainage class Code (values ranging from 1 to 6 ).

The DEM value map was used to delineate the boundaries of the geomorphic mapping units. The geomorphic mapping units were combined with the geological map using the capability of GIS software to produce the digital physiographic mapping units (Zinck, 1988). The fieldwork used to produce the final physiographic soil map of the studied area as shown in Table 2 and Figure 7. Results of laboratory analyses of representative soils profiles showed that there is variation soil in texture as presented in the study area, where soil texture varies from sandy loam to loamy sand texture with very high content of lime $(>25 \% \mathrm{CaCO} 3)$ in all soil profiles. For that, soil permeability is moderately rapid. Also, the fieldwork explained that soil structure of the soil profiles are massive. Organic matter content is very low and ranged from $0.11 \%$ to $0.44 \%$. Results obtained were integrated and distributed according to physiographic mapping units to produce K-factor map (Figure 8). 
Table 2:-Physiographic mapping units of wadi Umm Ashtan and wadi Umm El-Rakham

\begin{tabular}{|c|c|c|c|c|c|c|c|c|c|}
\hline \multirow{2}{*}{ Unit } & \multirow{2}{*}{ Landscape } & \multirow{2}{*}{ Relief } & \multirow{2}{*}{ Environment } & \multirow{2}{*}{ Landform } & \multirow{2}{*}{ Lithology } & \multicolumn{2}{|c|}{$\begin{array}{c}\text { Wadi Umm } \\
\text { Ashtan } \\
\end{array}$} & \multicolumn{2}{|c|}{$\begin{array}{l}\text { Wadi Umm } \\
\text { El-Rakham }\end{array}$} \\
\hline & & & & & & $\begin{array}{c}\text { Area } \\
\text { (ha) }\end{array}$ & $\%$ & $\begin{array}{c}\text { Area } \\
\text { (ha) }\end{array}$ & $\%$ \\
\hline CP572 & $\begin{array}{l}\text { Coastal } \\
\text { Plain }\end{array}$ & $\begin{array}{l}\text { Sand } \\
\text { Sheet }\end{array}$ & $\begin{array}{l}\text { Duricrusis, sand, } \\
\text { gravel, recent Coastal } \\
\text { deposit }\end{array}$ & Sloping area & $\begin{array}{l}\text { Marmarica } \\
\text { Formation }\end{array}$ & 166 & 1.6 & 477 & 5.7 \\
\hline CP111 & $\begin{array}{l}\text { Coastal } \\
\text { Plain }\end{array}$ & $\begin{array}{l}\text { Sea } \\
\text { Beach }\end{array}$ & $\begin{array}{l}\text { Duricrusis, sand, } \\
\text { gravel, recent Coastal } \\
\text { deposit }\end{array}$ & $\begin{array}{l}\text { Coastal } \\
\text { Plain }\end{array}$ & $\begin{array}{l}\text { Undifferentiated } \\
\text { Quaterrary } \\
\text { Deposits }\end{array}$ & 65 & 0.6 & 589 & 7.0 \\
\hline NPU383 & $\begin{array}{l}\text { Northern } \\
\text { Plateau }\end{array}$ & $\begin{array}{l}\text { Coarse } \\
\text { Valley }\end{array}$ & $\begin{array}{l}\text { White shallow marine } \\
\text { limestone with } \\
\text { interbedded marl }\end{array}$ & $\begin{array}{l}\text { Coarse } \\
\text { Valley, } \\
\text { Outer }\end{array}$ & $\begin{array}{l}\text { El Hagif } \\
\text { Formation } \\
\text { Deposits } \\
\end{array}$ & 395 & 3.7 & 371 & 4.4 \\
\hline NPU373 & $\begin{array}{l}\text { Northern } \\
\text { Plateau }\end{array}$ & $\begin{array}{l}\text { Coarse } \\
\text { Valley }\end{array}$ & $\begin{array}{l}\text { White shallow marine } \\
\text { limestone with } \\
\text { interbedded marl }\end{array}$ & $\begin{array}{l}\text { Coarse } \\
\text { Valley } \\
\text { Innear }\end{array}$ & $\begin{array}{l}\text { El Hagif } \\
\text { Formation } \\
\text { Deposits }\end{array}$ & 232 & 2.2 & 227 & 2.7 \\
\hline NPU113 & $\begin{array}{l}\text { Northern } \\
\text { Plateau }\end{array}$ & Plateau & $\begin{array}{l}\text { White shallow marine } \\
\text { limestone with } \\
\text { interbedded marl }\end{array}$ & Escarpment & $\begin{array}{l}\text { El Hagif } \\
\text { Formation } \\
\text { Deposits }\end{array}$ & 168 & 1.6 & 370 & 4.4 \\
\hline NPU123 & $\begin{array}{l}\text { Northern } \\
\text { Plateau }\end{array}$ & Plateau & $\begin{array}{l}\text { White shallow marine } \\
\text { limestone with } \\
\text { interbedded marl }\end{array}$ & $\begin{array}{l}\text { Low } \\
\text { Pedimont }\end{array}$ & $\begin{array}{l}\text { El Hagif } \\
\text { Formation } \\
\text { Deposits }\end{array}$ & 1054 & 10.0 & 2499 & 29.9 \\
\hline NPU133 & $\begin{array}{l}\text { Northern } \\
\text { Plateau }\end{array}$ & Plateau & $\begin{array}{l}\text { White shallow marine } \\
\text { limestone with } \\
\text { interbedded marl }\end{array}$ & $\begin{array}{l}\text { Moderately } \\
\text { high } \\
\text { Pidmont } \\
\end{array}$ & $\begin{array}{l}\text { El Hagif } \\
\text { Formation } \\
\text { Deposits } \\
\end{array}$ & 1958 & 18.5 & 1590 & 19.0 \\
\hline SPU182 & $\begin{array}{l}\text { Southern } \\
\text { Plateau }\end{array}$ & Plateau & $\begin{array}{l}\text { Shallow marine } \\
\text { platform limestone } \\
\text { with few marle }\end{array}$ & $\begin{array}{l}\text { High } \\
\text { Pidmont }\end{array}$ & $\begin{array}{l}\text { Marmarica } \\
\text { Formation }\end{array}$ & 6546 & 61.8 & 2247 & 26.8 \\
\hline \multicolumn{6}{|c|}{ Total Area } & 10584 & 100 & 8369 & 100 \\
\hline
\end{tabular}
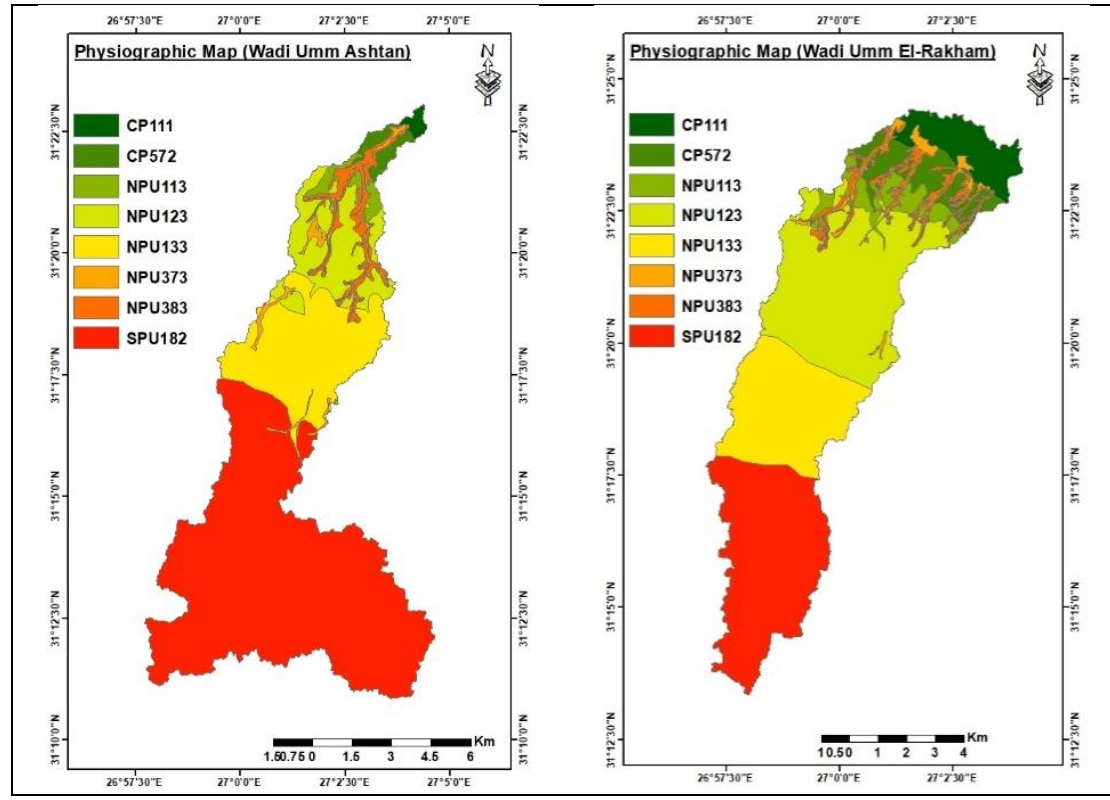

Figure 7:-Physiographic Units Maps of wadi Umm Ashtan and wadi Umm El-Rakham 


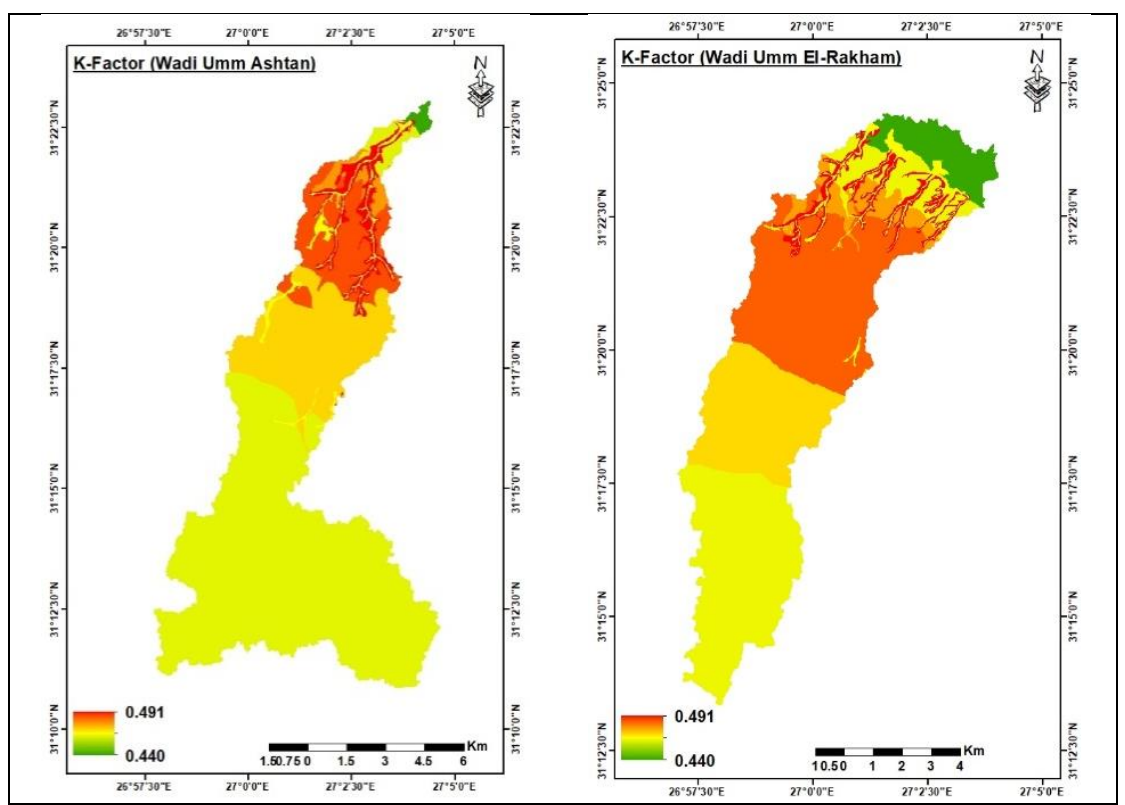

Figure 8:-K-Factor Maps of wadi Umm Ashtan and wadi Umm El-Rakham

\section{Slope and Slope Length Factors (LS)}

LS (Slope and Slope Length) factor was calculated for the study area using ArcGIS software using the DEM according to equation proposed by Moore and Burch (1986 a, b) as shown:

$$
\mathrm{LS}=\left(\frac{\text { Flow Accumulation } \times \text { Cell Size }}{22.13}\right)^{0.4} \times\left(\frac{\text { Sin }(\text { Slope } \times 0.01745)}{0.0896}\right)^{1.4} \times 1.4
$$

Where, flow accumulation, and slope degree value were computed from the DEM using ArcGIS software with the addition of cell size of grid cell $(12.5 \mathrm{~m})$ as shown in figure 9 :

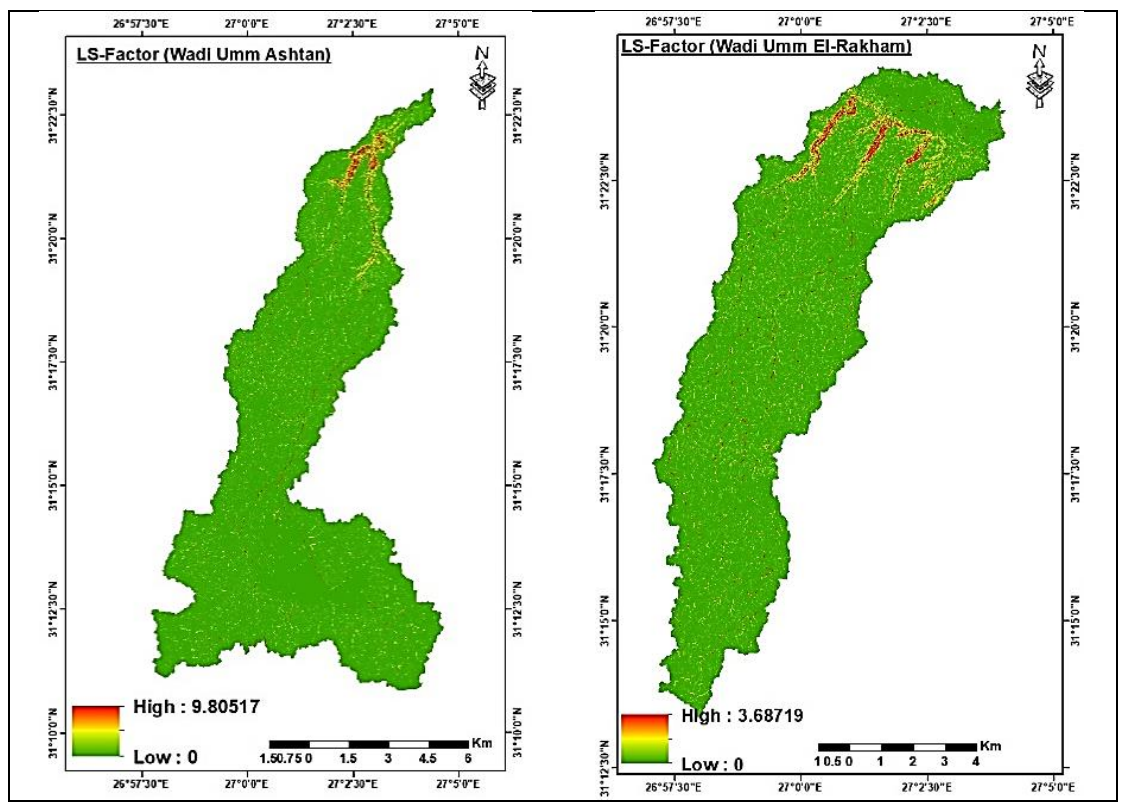

Figure 9:-LS Factor of wadi Umm Ashtan and Wadi Umm El-Rakham

Results show that LS factor values of wadi Umm Ashtan ranged from 0 to 9.8 while the values of Wadi Umm ElRakham ranged from 0 to 3.68. Where LS values increases with the increasing in slope degree thus the capability of soil erosion increases. 


\section{Cover management factor $(\mathbf{C})$}

According to Supervised Maximum Likelihood classification of the study area, Wadi Umm Ashtan and Wadi Umm El-Rakham areas are classified to four land cover classes: Agricultural land, tree clad area, built-up land and wasteland. The overall accuracy of the classification was about $87 \%$. C-factor identified according land cover type as shown in Figures 10 and 11.

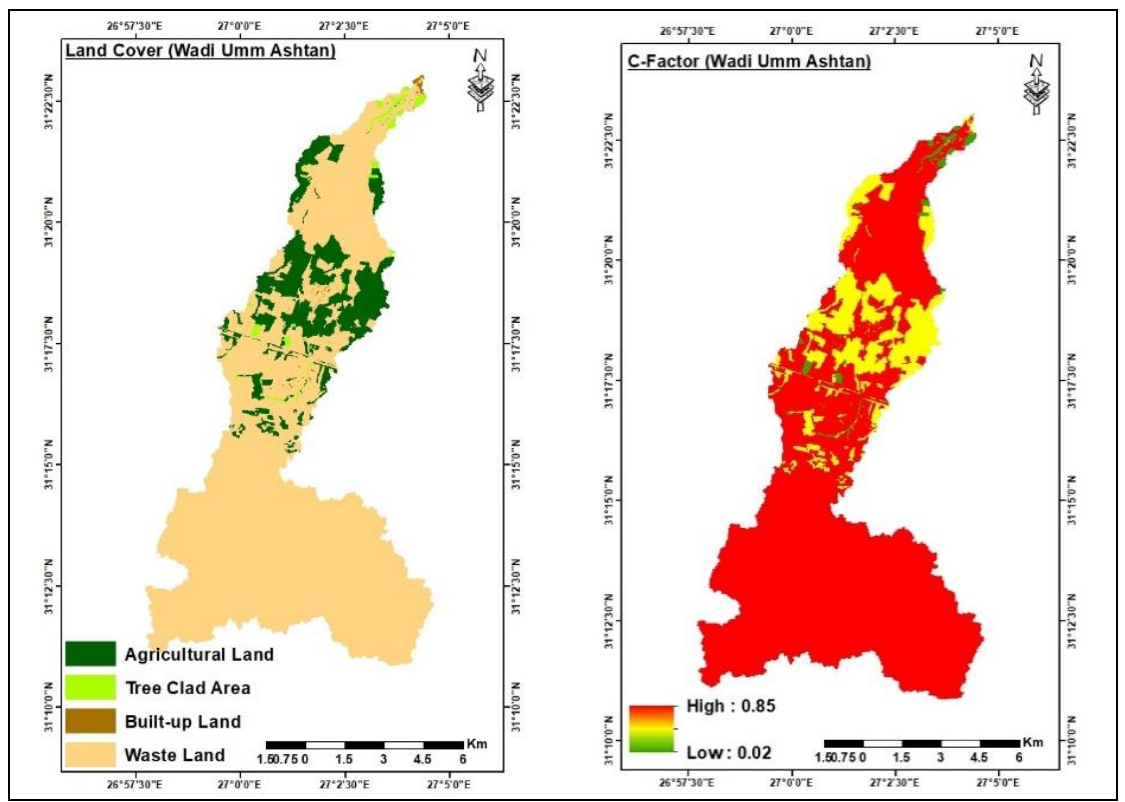

Figure 10:-Land cover and C-Factor of wadi Umm Ashtan

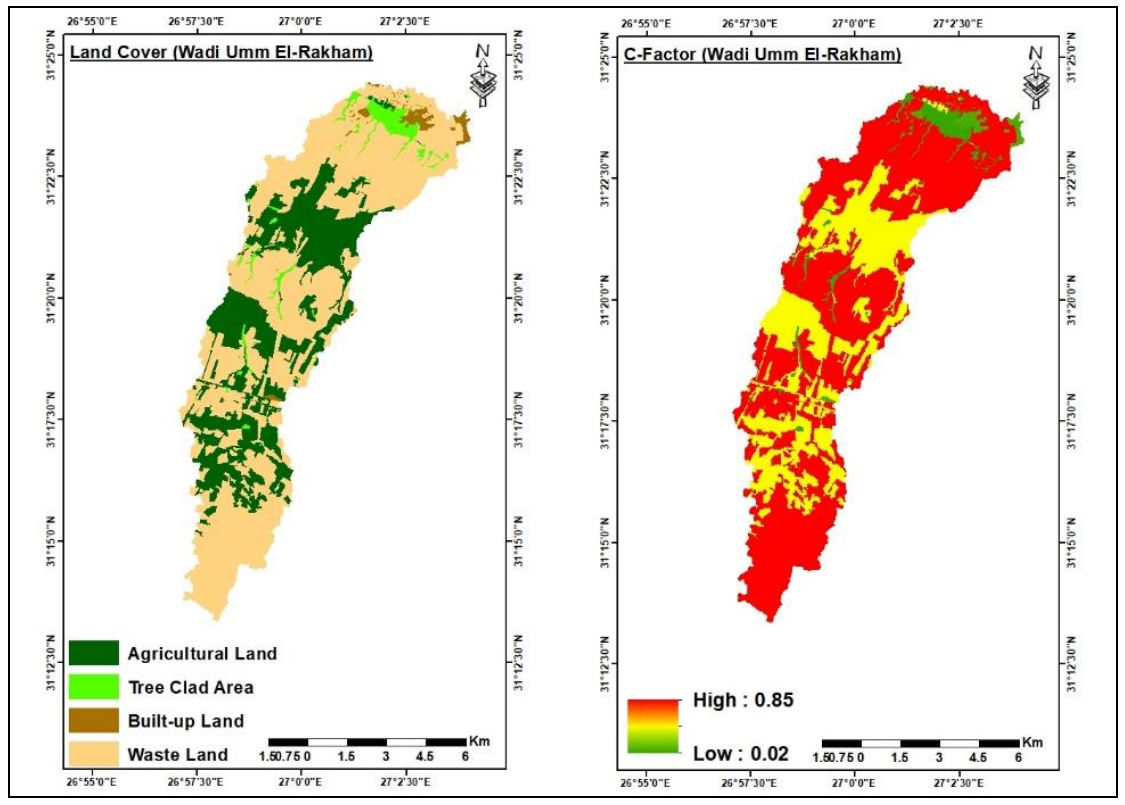

Figure 11:-Land cover and C-Factor of wadi Umm El-Rakham

Results also illustrates that c-factor values of Umm Ashtan and Umm El-Rakham wadies ranged between 0.02 to 0.85. Also, results indicate that c-factor values near to zero are located in areas considering high protected land cover of soil erosion such as forest and cropped areas. In case of the values near 1, these areas presents the poorly protected land cover of soil erosion such as barren areas. 


\section{The Support Practice (P Factor)}

P-factor map was generated in the present study from the land cover and support factors. P-factor values ranged from 0 to 1 (Figure 12), where, the highest value is assigned to areas with no conservation practices such as waste lands; while the minimum values assigned to areas with built-up-land and plantation area with strip and contour cropping Thus are increasing the efficiency of conservation practices.

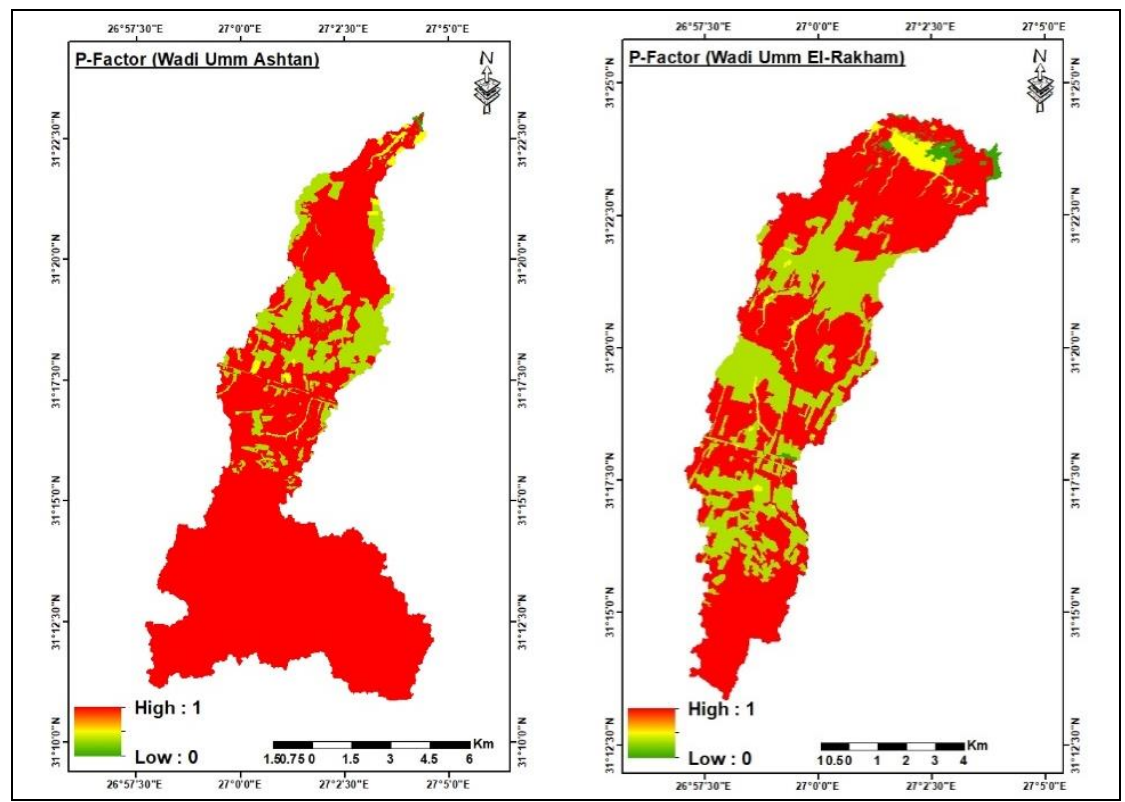

Figure 12:-P-Factor of wadi Umm Ashtan and wadi Umm El-Rakham

\section{Predicted soil erosion loss and soil erosion hazard}

According to RUSLE equation, Soil erosion map generated by overlaying RUSLE parameters maps (R-Factor, KFactor, LS-Factor, C-Factor and P-Factor) using raster algebra module in ArcGIS software as shown in Figure 13.

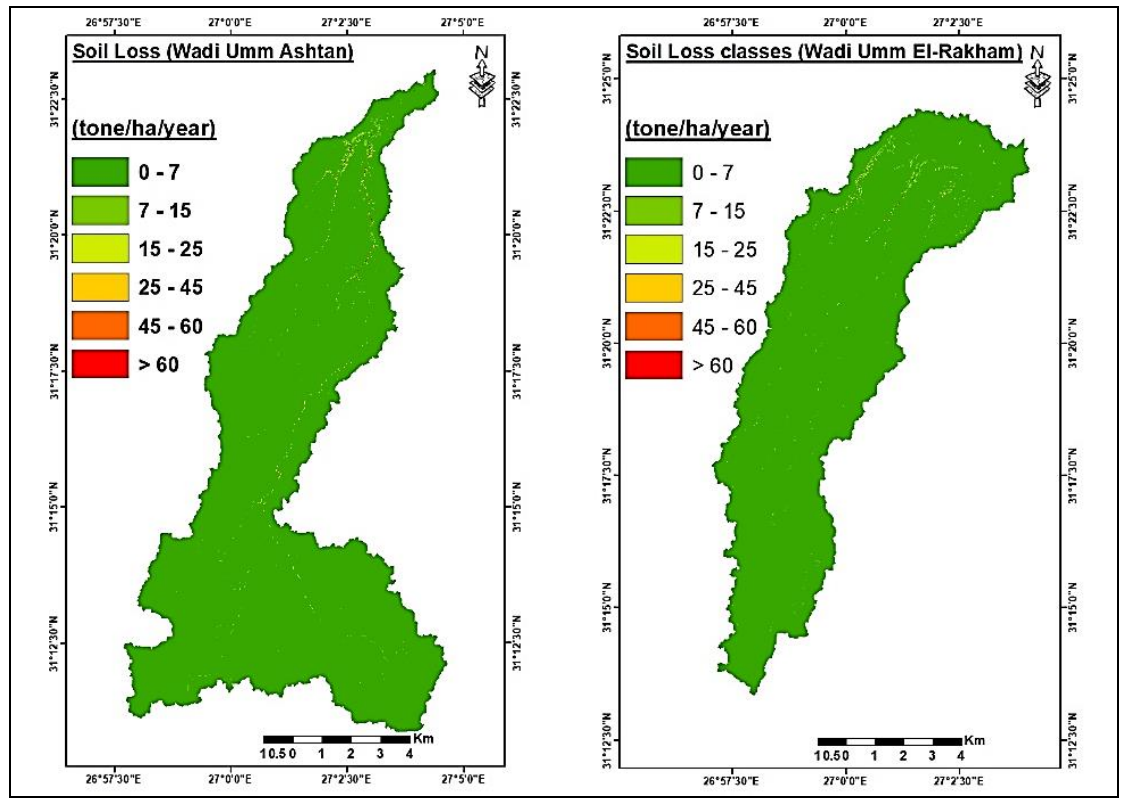

Figure 13:-Annual soil loss maps of wadi Umm Ashtan and wadi Umm El-Rakham

Depending on the results obtained, it was found that the highest value of predicted soil erosion of wadi Umm Ashtan is 562.8 tone/ha/year. As for wadi Umm El-Rakham, the highest value of predicted soil erosion is 211.6 
tone/ha/year. In both wadies these values are concentrated in the main streams in northern part of the wadis because of high length and steepness factor (LS-Factor) value.

According to erosion hazard classification suggested by Singh et al. (1992), Soil erosion of the study area is classified into 6 classes: Slight, moderate, high, very high, severe and very severe. (Table 3).

Table 3:-Soil loss rates, area coverage, and hazard classes

\begin{tabular}{|c|c|c|c|c|c|c|c|c|c|}
\hline \multirow{3}{*}{$\begin{array}{c}\text { Soil loss rate } \\
\left(\text { tone ha }^{-1} \text { year }^{-1}\right)\end{array}$} & \multirow{3}{*}{$\begin{array}{c}\text { Soil } \\
\text { Erosion } \\
\text { Hazard } \\
\text { Class }\end{array}$} & \multicolumn{4}{|c|}{ Wadi Umm Ashtan } & \multicolumn{4}{|c|}{ Wadi Umm El-Rakham } \\
\hline & & \multicolumn{2}{|c|}{ Area } & \multicolumn{2}{|c|}{ Annual soil loss } & \multicolumn{2}{|c|}{ Area } & \multicolumn{2}{|c|}{ Annual soil loss } \\
\hline & & ha & $\%$ & (tone) & $\%$ & ha & $\%$ & (tone) & $\%$ \\
\hline $0-7$ & Slight & 10522 & 99.4 & 36827 & 95.0 & 8308 & 99.3 & 29078 & 97.0 \\
\hline $7-15$ & Moderate & 40 & 0.4 & 440 & 1.0 & 47 & 0.6 & 517 & 2.0 \\
\hline $15-25$ & High & 10 & 0.1 & 200 & 1.0 & 8 & 0.1 & 160 & 1.0 \\
\hline $25-45$ & $\begin{array}{l}\text { Very } \\
\text { High }\end{array}$ & 7 & 0.1 & 245 & 1.0 & 4 & 0.0 & 140 & 0.0 \\
\hline $45-60$ & Severe & 2 & 0.0 & 105 & 0.0 & 1 & 0.0 & 53 & 0.0 \\
\hline$>60$ & $\begin{array}{c}\text { Very } \\
\text { Severe }\end{array}$ & 3 & 0.0 & 934 & 2.0 & 1 & 0.0 & 136 & 0.0 \\
\hline \multicolumn{2}{|l|}{ Total } & 10584 & 100 & 38751 & 100 & 8369 & 100 & 30083 & 100 \\
\hline
\end{tabular}

The classified soil loss map of wadi umm ashtan area shows that $99.4 \%$ of the total area falls under the slight with tolerable rate of $<7$ tone ha $^{-1}$ year $^{-1}$ which indicates that erosion is unlikely under ordinary climatic conditions, and produces about 36827 tons annually, followed by $0.4 \%$ of the total area which comes under moderate soil loss with tolerable rate of 7-15 tone ha $^{-1}$ year $^{-1}$, and produces about 440 tons annually, followed by $0.1 \%$ of the total area which comes under high and very high soil loss, and produces about 200 and 245 tons annually, respectively. The rest of the area is classified by very low areas of severe and very severe soil loss.

As for wadi umm El-Rakham results illustrated that $99.3 \%$ of the total area falls under the slight with tolerable rate of $<7$ tone $\mathrm{ha}^{-1}$ year $^{-1}$, which produce about 29078 tons annually, followed by $0.6 \%$ of the total area which comes under moderate soil loss with tolerable rate of 7-15 tone ha $^{-1}$ year- $^{-1}$, and produces about 517 tons annually, and followed by $0.1 \%$ of the total area which comes under high soil loss, and produces about 160 tons annually. The rest of the area is classified by very low areas of very high, severe and very severe soil loss.

The presence of most of wadi umm ashtan and wadi umm El-Rakham under slight soil loss class indicates that erosion is unlikely under ordinary climatic conditions. While moderate, high and very high erosion areas which may be due to the steep slope indicates that thus it needs great attention and erosion-control measures may be needed

\section{Conclusion:-}

The study proved that the soil erosion loss model RUSLE integrated with GIS is an effective tool for processing the large data required for soil loss studies in view of the traditional methods that proved too costly and time-consuming to extract input data. The results obtained can aid in the implementation of soil management and conservation practices to reduce the soil erosion in the studied areas.

Results illustrates that most of Wadi Umm Ashtan and Wadi Umm El-Rakham falls under the slight soil erosion hazard class while areas fall under medium and high soil erosion hazard classes where the highest value of predicted soil erosion was recorded and concentrated in the main streams in northern part of the wadis because of high length and steepness factor (LS-Factor) value. In these areas. All protection methods should be followed to minimize soil loss rate by increasing soil stabilization and vegetation density. It is recommended that model validation and testing should be carried out in future studies as this represents an important step towards developing more effective sediment yield modeling tools for nationwide applications. 


\section{References:-}

1. Angima, S.D., Stott, D.E., O’Neill, M.K., Ong, C.K. and Weesies, G.A. (2003): Soil erosion prediction using RUSLE for central Kenyan highland conditions. Agriculture, Ecosystems and Environment, 97 (1-3), pp. 295308.

2. Arnoldus, H.M.J. (1978): An approximation of the rainfall factor in the Universal Soil Loss Equation. In: De Boodt, M. \& Gabriels, D. (eds): Assessment of erosion, p. 127-132. Wiley, Chichester.

3. C.L.A.C. (2015): Central Laboratory for Agricultural Climate (CLAC) website. http://www.calc.edu.eg.

4. Dabral P.P., Baithuri, N. and Pandey, A. (2008): Soil erosion assessment in a hilly catchment of North Eastern India using USLE, GIS and remote sensing Water Resources Management, 22, pp. 1783-1798.

5. Edwards, K. (1987): Runoff and soil loss studies in New South Wales: Soil Conservation Service of NSW. Technical Handbook No. 10, Sydney.

6. ERDAS (2014): ERDAS IMAGINE handbook - Features Next-Generation Spatial Modeler". Retrieved 201403-11.

7. ESRI (2016): Arc Map version 10.4.1 User Manual. ESRI, 380 New York Street, Redlands, California, $92373-$ 8100, USA.

8. Lu D., Mausel, P., Brondizio, E. and Moran, E. (2004): Change detection techniques, International Journal of Remote Sensing, 25(12), pp.2365-2407.

9. Millward, A. and Mersey, J. (1999): Adapting the RUSLE to Model Soil Erosion Potential in a Mountainous Tropical Watershed. Catena, 38, 109-129.

10. Moore, I.D., and Burch, G.J. (1986): Physical basis of the length-slope factor in the Universal Soil Loss Equation. Soil Sci. Soc. Am. J. 50, 1294-1298.

11. Pandey, V.K., Panda, S.N., Pandey, A. and Sudhakar, S. (2009): Evaluation of effective management plan for an agricultural watershed using AVSWAT model, remote sensing and GIS. Environ. Geol., 56, 993-1008.

12. Renard, K.G., Foster, G.R., Weesies, G.A. and Porter, J.P. (1991): RUSLE: Revised Universal Soil Loss Equation. J. Soil and Water Conservation 46(1):30-33.

13. Sanjay K.J., Surhir, K. and Jose, V. (2001): Estimation of Soil Erosion for a Himalayan Watershed Using GIS Technique Water Resources Management 15: 41-54.

14. Simms A.D, Woodroffe, C.D, Jone, B.G. (2003): Application of RUSLE for erosion management in a coastal catchment, southern NSW. International Congress on Modelling and Simulation, volume 2, Integrative Modelling of Biophysical, Social and Economic Systems for Resource Management Solutions, Townsville, Queensland, 14-17 July 2003, 678-683.

15. Singh, G., Babu, R., Narain, P., Bhushan, L. S. and Abrol, I. P. (1992): Soil erosion rates in India. Journal of Soil and Water Conservation 47 (1): 97-99.

16. Soil Survey Staff, (2014): Keys to Soil Taxonomy, 12th Edition, NRCS - USDA, 1400 Independence Avenue, S.W.; Washington, D.C. 20250-9419.

17. UNESCO, (1977): Map of the World Distribution of Arid Regions, MAB Technical Notes, 7. U.S. Salinity Laboratory Staff (1954). Diagnosis and Improvement of Saline and Alkali Soils. U.S. Agriculture Handbook 60, U.S. Department of Agriculture, $160 \mathrm{pp}$.

18. USDA (2004): Soil Laboratory methods. Soil Survey Investigation. Report No 42 version 4 .0 November 2004

19. Van der Knijff, J.M., Jones, R.J.A. and Montanarella, L. (2000): Soil erosion risk assessment in Europe. European Soil Bureau. EUR 19044 EN, 36pp.

20. Wischmeier, W. H. and Smith, D.D. (1978): Predicting rainfall erosion losses. Agr. Handbk. 537. U. S. Dept. Agr., Washington, D.C.

21. Zinck, J. A. (1988): Geomorphology and Soils. Internal Publ., ITC., Enschede, The Netherlands. 